\title{
Notes on the vocalizations of Flavescent Bulbul (Pycnonotus flavescens)
}

Peter Boesman

In the following we briefly analyze and compare voice of the different races of Flavescent Bulbul (Pycnonotus flavescens). We also try to quantify the extent of any vocal differences using the criteria proposed by Tobias et al. (2010), as a support for taxonomic review.

We have made use of sound recordings available on-line from Xeno Canto (XC) and Macaulay Library (ML).

Our main interest is to compare voice of mainland races with the disjunct Bornean race leucops:

Mainland races

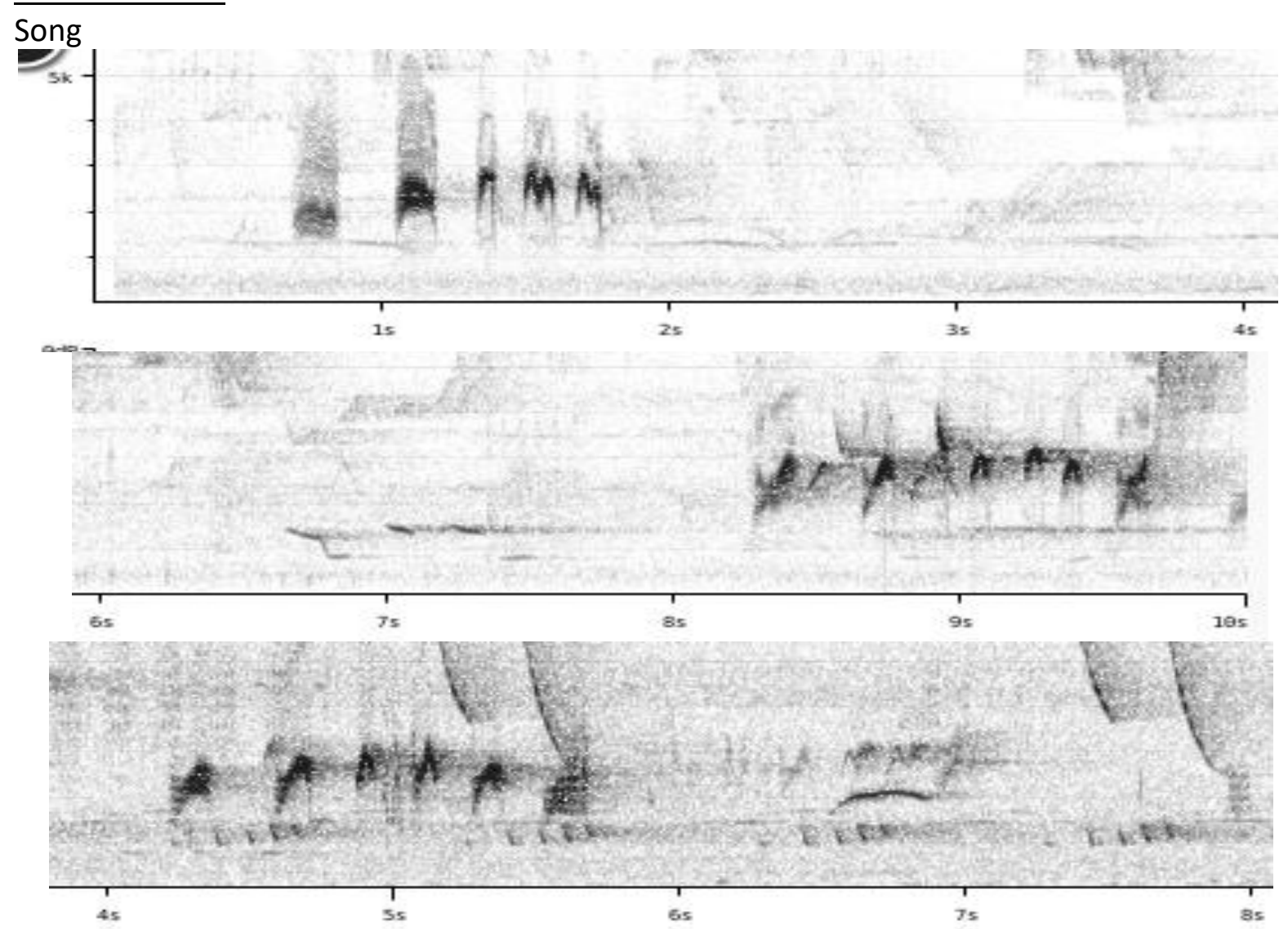

Calls

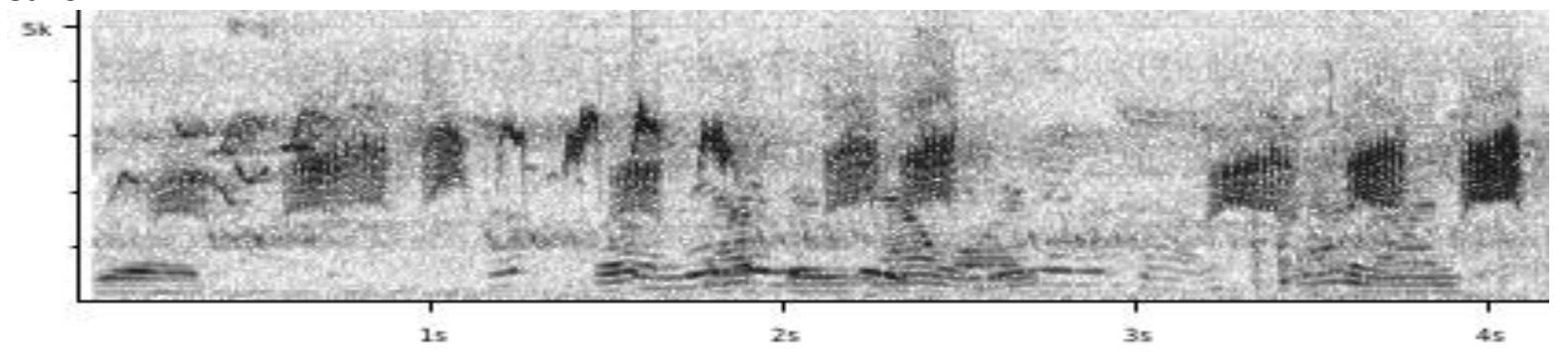




\section{HANDBOOK OF THE \\ Allue}

\section{ORNITHOLOGICAL NOTES}
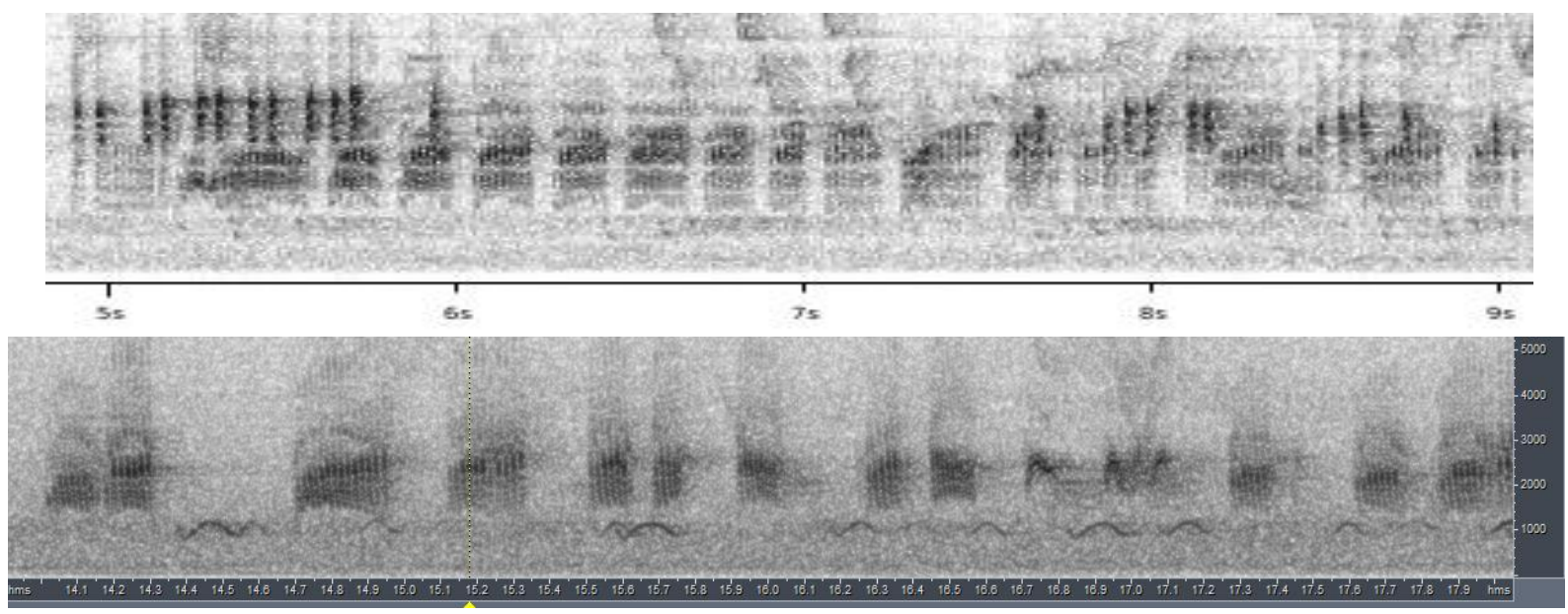

\section{leucops (Borneo)}

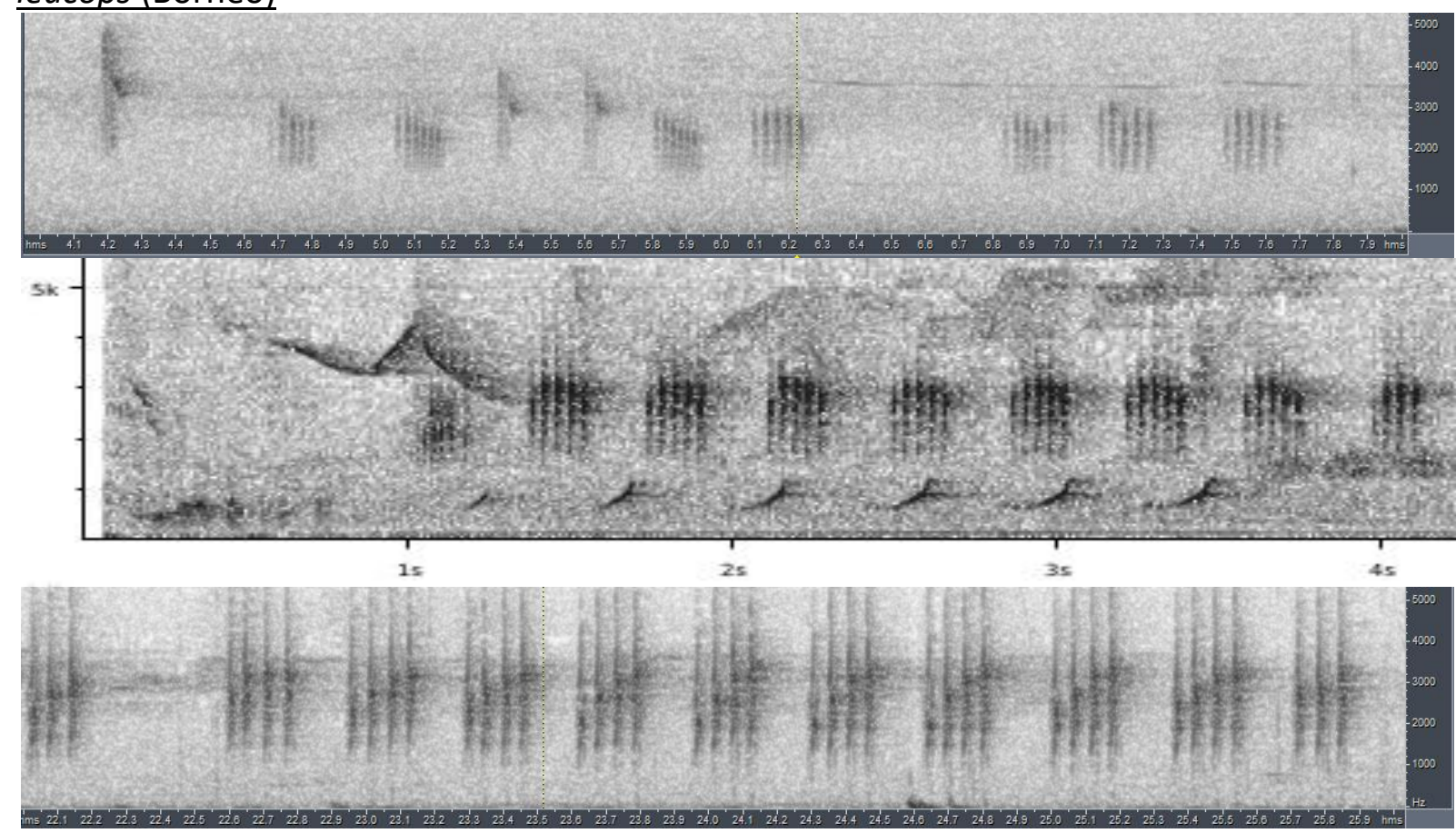

There are only a few recordings available of leucops. Apparently no song has been recorded, or else this taxon lacks the equivalent to the mainland song.

Above vocalizations from Borneo seem rather the homologous vocalization of the rattling call notes from the mainland, but there is a clear difference in rattling pace and number of notes in a rattle. If this vocalization proves to be the main vocalization of leucops, then obviously this difference becomes important and a scoring for vocal difference could be based on pace (2-3) and number of notes (2). 
This note was finalized on 22nd February 2016, using sound recordings available on-line at that moment. We would like to thank in particular the sound recordists who placed their recordings for this species on XC and ML: Patrik Åberg, Desmond Allen, David Edwards, David Farrow, Ross Gallardy, Ben King, Frank Lambert, Tero Linjama, Hans Matheve, Mike Nelson, Mark Robbins, Arnoud Van den Berg.

\section{References}

Tobias, J.A., Seddon, N., Spottiswoode, C.N., Pilgrim, J.D., Fishpool, L.D.C. \& Collar, N.J. (2010). Quantitative criteria for species delimitation. Ibis 152(4): 724-746.

\section{Recommended citation}

Boesman, P. (2016). Notes on the vocalizations of Flavescent Bulbul (Pycnonotus flavescens). HBW Alive Ornithological Note 245. In: Handbook of the Birds of the World Alive. Lynx Edicions, Barcelona. (retrieved from http://www.hbw.com/node/932242 on 30 September 2016). 